\title{
A Narrative Literature Review on ESL Business English Instruction
}

\author{
Dr. Andrew Szanajda \\ Associate Professor, Applied English Department \\ Overseas Chinese University, Taichung, Taiwan, Roc \\ Wei-Yu Chang
}

School of Education Durham University. Durham University. Durham, UK

\begin{abstract}
This paper examines the effectiveness of grammar instruction in English business writing classrooms. The issue of whether grammatical accuracy ought to be emphasized has been debated among different researchers. Some have argued that one's grammatical accuracy is an important factor to write coherently. Coherence has been deemed as one of the most difficult aspects for ESL learners to master, which is of a major impact on one's writing quality. On the other hand, others have maintained that grammar could influence one's writing abilities by reducing their language learning motivations and attitudes. In addition, not only is written language involved in business English, but one's verbal abilities are also considered to be fundamental communicative tools in business English field. Listening abilities are therefore of importance in learning business English because one's listening abilities are decisive to one's learning efficacy, which decides how much input one could receive and understand, such as grammatical knowledge. After going through the extant literature in a narrative method, this paper therefore suggests that one's language understanding, fluency, and coherence can be founded on their grammatical abilities, which are delivered through listeningbased learning. As a result, both listening abilities and grammatical knowledge are closely related to each other in one's business English learning process. Finally, it has been concluded that teaching grammar in ESL business writing education is necessary although there are some latent factors of being detrimental to one's learning. However, it is crucial for language learners to be competent at business English practically outside of classrooms, ESL learners in particular.
\end{abstract}

Keywords: Grammar Instruction, Grammatical Accuracy, Business English

\section{INTRODUCTION}

The purpose of this work is to determine the specific usefulness of teaching grammar in the context of teaching business ESL. Having a grammar focus is inherently connected to coherence in the instruction of ESL writing and speaking, and both of these elements of ESL learning are crucial for business ESL learners to master if they are to be able to conduct business in English outside the classroom environment. There are multiple approaches to teaching business ESL, many of which involve intensive, immersive or fast-track ways of learning. Because of these educational contexts, there is a partial division among ESL instructors regarding the importance of a specifically grammarbased approach while delivering four skill contents in a Business English course that should involve having a combination of speaking, listening, reading and writing, with the underlying factor of whether being able to communicate should focus on grammatical accuracy, and how this is to be undertaken. English is a language with sometimes idiosyncratic and complex grammar structures and rules, and focusing on grammar in the context of instructing business ESL learners requires examining whether grammatical accuracy ought to be emphasised. This work will focus on ESL teaching to business students in particular in view of synthesising earlier secondary works on instruction in different language skills, and whether a grammar-focused approach is the most useful approach in the long-term for a four skills approach to learning business English, in view of writing and reading as one way communication and listening and speaking as two way forms, while there are the underlying factors of forwarding ideas along with grammatical accuracy. It is recommended that there should be a focus on listening as a means of serving as an implicit approach for learning grammar before grammatical accuracy could be emphasised as a secondary priority. 
Much of the discourse in the literature regarding the relevance of grammar-specific teaching in business ESL for students relates to their development of coherence. Coherence in writing is undoubtedly one of the most difficult aspects for ESL students to master. Without there being coherence in writing samples, it is very difficult for students to qualify contents in a foreign language, and this is particularly relevant in the context of business-related practices where clarity as well as simplicity are to be expected. Effective communication cannot occur without mutual coherence in English, which is closely connected to grammatical knowledge and at least awareness of rules to be applied. Even relatively minor problems regarding coherence can quickly cause a partial or total breakdown of comprehension and communication, whether in written, aural or verbal forms (Hellalet, 2013). English language instructors in the field of business therefore emphasize linking the development of both coherence and grammar. The potential usefulness of grammatically-based ESL teaching to improve English learners' coherence and functionality in their writing, speaking and communication in general is thus to be examined. One fundamental focus of this study is to determine whether there is a direct relationship between grammatically-based ESL teaching and the development of coherence and functionality, and thereby also bolster student confidence in business ESL usage that is targeted at being applied in real world applications in the contexts of business communications. The diverse contexts of grammatically-based ESL teaching are to be assessed in order to understand how intersecting factors may have positive effects on effectively functioning in a business context in English. Does a grammatically-based approach to business ESL education improve outcomes for students?

\section{Methodology}

The research methodology for this work is a secondary data analysis following a broad literature review. Data has been gleaned from the relevant literature, focusing on the most recently published studies. The initial phase is a broad-ranging narrative literature review - an analysis of a section of published literature within a specific field (Greenland \& O' Rourke, 2008; Bordens \& Abbott, 2008). In this case, focus is on ESL instruction for business, and the role and function of a grammaticallyfocused approach in such educational efforts that has been synthesised. The literature review format chosen is that of narrative literature review, rather than a systematic or meta-analysis/meta-synthesis approach (Greenland \& O' Rourke, 2008). International and regional studies have also been integrated into the literature review, allowing for a broad view of the current situation regarding grammaticallyfocused ESL teaching as it relates to business usages and functions.

\section{LITERATURE REVIEW}

For a learner of the English language for business uses, an understanding of various forms of grammatical accuracy is absolutely necessary if an individual is to communicate clearly and coherently. However, whether the grammatical understanding is explicit or implicit is not necessarily important in terms of developing coherence and functionality. Chin (2005) notes that learners' experiences and attitudes regarding grammar vary quite significantly in typical language use. For those individuals who are English native speakers, applying grammar in a verbal context may be quite intuitive, rather than being explicitly based on known grammatical rules (Chin, 2005). However, even when a native speaker or experienced learner of business English has a good intuitive grasp of verbal grammar - based on whether their words and English usage "sound" or "feel" correct - this may not necessarily be transferred to written forms when that same individual needs to communicate in written English. Skilled non-native English speakers may thus lose coherence and efficiency of communication when the medium of communication is written rather than verbal. This likewise applies to listening when contents are subject to the listener's comprehension based on recognising vocabulary and grammar patterns, whether it is in the form of one or two way communication. Chin (2005) suggests that ESL teachers may find it helpful in the educational context to build upon students' intuitive grasp of verbal grammatical rules, which can be then used to connect to the practice of communication through coherent writing.

\section{Grammatical Accuracy Or Fluency as the Priority Focus?}

Shen (2012, pp.74-75) notes that English-language writing coherence, grammatical understanding and comprehension have been undermined as a result of globalisation. The English language is used globally for business, education and entertainment purposes. However, the role of writing within such globalised communications has been perhaps reduced overall (Shen, 2012). Shen (2012) argues that 
grammatical problems often lie at the root of ineffective or confusing written English among ESL learners, noting that common grammar-related problems that reduce meaning or clarity include fragmented sentences, problems with punctuation, among other grammatical mistakes that distort the meaning or intent of communication. Digital technology and interconnectedness through online access has had an often detrimental effect upon the grammatical knowledge and written Englishlanguage skills of native speakers and ESL learners alike. Spelling skills and common grammar usages are two examples of language skills having been reduced overall as people increasingly rely upon automated spell-checkers (Shen, 2012). Spell-checkers are effective at correcting individual words, but their grammatical function is not usually sufficiently nuanced to detect grammatical errors that can undermine clarity. Therefore, there is a need for English language learners to learn the rules of grammar for themselves, instead of relying upon automated corrections by using different forms of software.

In the extant literature, opinion is divided regarding whether a grammatically-based educational approach improves overall English fluency, coherence and communicative ability. Williams (2011, pp.278-279) states that some study subjects performed better on English language fluency tests when they had not received formal instruction or education regarding the grammatical rules and conventions of the language. One study measuring student ability in English-language usage, spelling, punctuation and sentence structure found that students with specific grammar instruction achieved better than students without such instruction in only one category - usage (Williams, 2011, pp.278-279). According to other English-language metrics involving testing and measuring, the students who had not received instruction often outperformed their counterparts who had received grammatically-based instruction (Williams, 2011). Williams (2011, p.279) further notes that grammar-focused ESL instruction can fail somewhat to reach course objectives when students consider it to be unnecessarily repetitive. The motivation and even enjoyment level of ESL learners are connected to their learning experiences and their attitudes towards English learning and usage. Williams (2011) indicates that students who did not experience grammatically-focused ESL instruction generally had a more positive language learning experience, and therefore generally had more enthusiasm in general towards English language use (Williams, 2011). Williams (2011) can be understood as supporting the literature sources that views specific grammar instruction as primarily being a hindrance in the development of English-language coherence and fluency among ESL learners for business or other purposes.

Lancaster and Olinger (2014) appear to agree with Williams (2011), noting that "explicit grammar instruction has no effect or even a harmful effect on students' writing development" (p.1). Hudson (2001, p.6) finds a positive effect of grammatically-focused ESL instruction, claiming that writing skills are certainly strengthened and improved when a grammatical educational approach is taken. However, it should be considered that Hudson's research involved ESL learners who were children. In the context of ESL for business purposes on the other hand, the students are more likely to be adults whose uses of English will be based on professional needs. Hudson (2001) notes, however, that the field of research into grammar and ESL teaching remains somewhat sparse, stating that further research is definitely needed in this area. Noguchi (1991) states that grammar-based teaching could be expected to contribute to achieving coherence in students' written English tasks. Specifically, Noguchi states that teaching exercises involving combining English sentences that are individually too concise can help students to understand grammatical rules, and how these affect meaning, writing style and communication efficiency.

Micciche (2004) indicates that a grammatically-based instruction approach "encourages students to view writing as a material social practice in which meaning is actively made, rather than passively relayed or effortlessly produced" (Micciche, 2004, p.716). Social context certainly affects students' achievements when communicating in English (Jones, Myhill \& Bailey, 2013). Therefore, grammarbased studying can be applied as an active approach to ESL learning. Micciche (2004) advocates returning to grammatically-based ESL teaching, despite its status as being "unquestionably unfashionable" (Micciche, 2004, p.716). Micciche is reasonably convincing in arguing that grammatically-based ESL teaching before students begin drafting work in English would serve to place strong grammatical foundations at the outset. According to Micciche, this would be preferable to a teaching method in which grammatical rules are applied retroactively as an attempted "repair" or correction of grammatically-weak writing. 
Hinkel (2013) outlines research-supported grammatically-based ESL teaching as it relates to academic writing. Although academic writing and business writing in English are different fields and modes of communication, there are nevertheless significant commonalities between these two types of English usage for ESL learners - both involve some degree of research, presenting facts and opinions, and often a discursive mode of writing in which coherence is of high importance. There are specific English-language requirements relating to grammar and usage that are necessary in effective academic writing, and the same could be said for effective business writing and speaking, as well as listening, especially when contents received are to be interpreted accurately before offering pertinent responses through writing or speaking as forms of one way communication. Overall, there is a divide in the extant scholarly literature as it relates to considering the effectiveness of a grammatically-based ESL teaching. However, the arguments that a grammatically-based ESL teaching has a broadly positive effect upon written English usage specifically, and this has relevance for the education of those students who will be using their English language skills in a business context, particularly when writing ability is required.

However, business English usage requires verbal skills and fluency as two way communication in addition to writing as one way for an unseen audience without there being face to face contact, and therefore it is necessary to consider how it relates to speaking and listening. Notably, a great deal of English-language learning occurs through the medium of listening, and therefore listening skills are of critical importance in English learning, whether or not the instruction is grammatically-based. Listening comprehension develops as a kind of accumulation of the student's existing learning through exposing them to vocabulary and grammar patterns that can be reproduced, and it is also commonly used as a way of testing vocabulary and grammar that has been classroom-learned. In the context of the real world, students will be putting their English-language skills to use as business practitioners in various situations in which there could be variations to be faced. British English, in particular, can be difficult to comprehend due to the diversity of regional accents and dialects, as well as British English vocabulary (Adank, Evans, Stuart-Smith \& Scott, 2009). Furthermore, among speakers of American English, there are diverse regional accents and patterns of usage - the international business practitioner must be able to listen to, and comprehend, many different pronunciation patterns and accents in English. For this reason, Hamouda (2013) posits that the listening ability is "one of the important skills in foreign language learning" (Hamouda, 2013, p.113).

Hamouda's research (Hamouda, 2013) found that "accent, pronunciation, speed of speech, insufficient vocabulary, different accent of speakers, lack of concentration, anxiety, and bad quality of recording were the major listening comprehension problems encountered by EFL [learners]" (Hamouda, 2013, p.113). Bloomfield, Wayland, Rhoades, Blodgett, Linck \& Ross (2000) indicate an understanding of typical listening difficulties experienced by students can lead to more effective future teaching among ESL instructors and educators. Instructors need to develop an understanding of the problems their students encounter when listening to English tasks and conversations, and then be guided as to the most effective use of grammar as it relates to both learning through listening and practicing using learned English in a verbal or aural context. Instruction should therefore followed a specific grammar focus to be exercised during listening or speaking practice, which could in turn be recognised in reading as a means of assisting with implicit grammar learning through its visual form, and learning sentence patterns, collocations or vocabulary, or applied through writing. Moreover, setting forth sources of practice contents for grammar patterns to be reproduced through listening should also be selected in view of appropriate listening contents. The authors of this work thus maintain this is to be added to business English course contents in view of certain practical considerations.

\section{FocUSing ON ENHANCING LISTENING SKILlS}

Bejar, Douglas, Jamieson, Nissan \& Turner (2000) indicate that much of the English-language input for learners is in a listening format, even if much of the educational material used in ESL classes may be in written format. Chen (2002) reinforces this concept of listening material as the primary input source for language learning, both in the classroom and in the real-world context. It is not possible to achieve fluency and mastery in ESL only through reading and writing, without also undertaking listening exercises and experience as part of the process of learning the language (Chen, 2002). Hellalet (2013) underlines the importance of listening to learned vocabulary for fluency and comprehension. Particularly and specifically in the listening context, there may be a high degree of variation and nuance regarding the speed of speech, pronunciation and regional accents (Adank, 
Evans, Stuart-Smith \& Scott, 2009). Blau (1990) further notes that comprehension of English language in the listening context is affected by syntax, speech rate, pauses and the rate of such pauses all affect listening comprehension overall. Listening is "a critical priority among the four skill areas for language student"' (Hamouda, 2013, p.113). Hasan (2000) argues how listening comprehension provides suitable conditions for language acquisition and also the development of other language skills (p.138).

Gilakjani and Ahmadi (2011) argue that listening comprehension is in fact the major part of English language comprehension for ESL students, and listening comprehension is closely related to grammatical knowledge, if not specifically grammatically-focused education in ESL for business. According to Chen (2002), it is implied that listening as the primary input for ESL learners means that listening is also the primary conduit for learning grammar rules, which could in turn be reproduced in students' writing and speaking. However, this is more likely to occur in an implicit rather than explicit manner when the student is listening rather than reading or writing. Therefore, listening could be considered as a prime and intuitive channel for ESL business students to understand how to use grammatical rules of English through exposure to how they are used, without necessarily undergoing rules-based classroom instruction. This is particularly relevant for students who may be studying ESL in remote or online contexts, by perhaps being assigned recorded or broadcast audio material to listen to in English outside a classroom setting, as technological development and the Internet allow students to be assigned listening and speaking assignments remotely or independently (Chapelle, 2003).

One important aspect of business ESL instruction is that it may well involve self-directed learning as students study online or remotely. Classroom instruction in combination with work students do on their own computers is considered "blended learning." Research indicates blended learning leads to an experience of learning in a community that is comparable to a traditional classroom learning (Rovai and Jordan, 2004; Akkoyunlu and Soylu; 2006). Students can work at their own pace while undertaking research according to their own interests, and also being engaged in ESL business studies (Faizah and Hazadiah, 2010). Online listening materials are widely and freely available in a costeffective option for the teacher and the student alike. Literature sources indicate that listening is similarly important for the ESL student, as it is in the "real world" for the business practitioner who is also an English language learner (Rost, 2002). However, Hamouda (2013) states how EFL learners face serious problems with English listening comprehension since universities mainly emphasize English grammar, reading and vocabulary, rather than listening and speaking skills. It is therefore presumed that it will somehow develop naturally and indirectly through the process of language learning (Hamouda, 2013, p.214). It is therefore to be maintained that listening contents that are administered should include a grammar component to be detected among the contents, and thereby maintain a grammar focus in the listening components of a course.

Language as an auditory and heard element appears to be the primary facet of English language learning and comprehension for students. Yet, this is not demonstrated in the balance of writing, speaking, reading and listening in standard ESL learning situations. Problems relating to listening comprehension clearly have potential negative effects upon grammatical knowledge and use of ESL in a business or educational context, as it is understood that grammatical knowledge - implicit or explicit - affects usage and coherence in English. Listening involves "perception, attention, cognition, and memory" (Hamouda , 2013, p.117), which closely relate to English-language functioning and grammatical use. Hayati (2010) identifies elements that can affect engagement with listening materials in English language: rate of speech is crucial as ESL learners typically find it difficult to process the fast pace of speech by native English speakers (Hayati, 2010). The choice of topic also is relevant to listening comprehension, as students will be less able to comprehend English-language discussion of topics or subject matter with which they are unfamiliar (Chiang \& Dunkel, 1992). As mentioned previously, and as it relates to the decision whether or not to use a grammatically-based ESL instruction approach, listening materials are found by some researchers to be more motivating for students than reading and writing materials (Hayati, 2010; Boekaerts \& Niemivirta, 2000). However, 
there is also the underlying factor of emphasising accuracy of comprehension, and therefore students ought to focus on specific grammar patterns found in the listening.

Listening is also important in order for students to generalise the grammatically-based ESL instruction they have received, so that certain grammatical rules and vocabulary items can be understood in the context of varying pronunciation, speech pace, and regional accent or dialect. Hasan (2000) indicates some factors that may have a negative effect on listening comprehension for the ESL learner: new vocabulary causes problems, as can a grammatical structure that is complex or idiomatic. Furthermore, the length of the text used for listening can cause difficulty in overall comprehension levels (Williams, 2011; Shen, 2012). A longer text can interrupt or derail comprehension or attention on the part of the student (Lin, 2000; O'Malley, Chamot \& Kupper, 1989; Boekaerts \& Niemivirta, 2000). The high prevalence of idiomatic speech in English language can confuse a student even when they are aware of both the vocabulary and the grammar being used (Chang, Chang \& Kuo, 1995; Bell, Brenier, Gregory, Girand \& Jurafsky, 2009). There are regional idioms of English language usage in business and in other fields (Adank, Evans, Stuart-Smith \& Scott, 2009). Grammatical rules and usage also may differ somewhat between regions and areas.

The ESL educator's goals and approach ought to be grounded in the needs, professional requirements and expectations of the student body (Freire, 2013). English language skills education should ideally be connected to English-language cultural education, particularly as this will help the students when they will use their knowledge and skills in a business context (Ghanem, 2015). Diverse and generalized English-language instruction will aid the student in communicating in a business or a social context. A stronger understanding of grammatical rules and foundations to the English language will help in both contexts, and as they are interconnected the strength developed in social English will transfer to the business context, and vice versa. It is ideally necessary in the classroom context for the ESL educator to impart real-life English-language skills, and these also include generalization of grammatical rules and grammatical exceptions - verbal English, particularly, can be relatively less predictable in practice than in a "textbook" context (Friere, 2013). Strategic business English usage in the professional context requires students to be pre-emptively equipped to cope with potentially unpredictable linguistic situations. Grammar will help with generalization, although there is a balance to be struck between an overtly grammatically-based educational approach and the retention and fostering of student enthusiasm for the English-language learning experience in general (Zhao, 2013).

According to Bloom's Taxonomy, learners acquiring and understanding a particular type of knowledge can then apply, analyze, and synthesize that knowledge (Bloom, 1956). Many ESL students have trouble explaining their expectations and needs in undertaking to learn English, and this is true in the business context as well as in other or general fields of ESL learning. As it relates to grammar and the use of a grammatically-based instructional approach, the ESL educator should be aware that many students may need to learn grammar without necessarily expressing any wish to do so. The educator's role is to pre-emptively understand and allay inhibitions about ESL learners expressing their needs as it relates to grammatical learning. Clearly, grammar-based learning is necessary in some form if a student is to achieve coherence and fluency.

Smith (2000) indicates that adult learners are often empowered by extrinsic motivation, which makes it possible to use self-directed study in business ESL at least some of the time. Students may acquire grammatical knowledge and understanding without specifically setting out to study grammar of the English language - this may happen quite naturally if the students are assigned or encouraged to pursue independent projects and studies in ESL topics that interest and engage them (Williams, 2011; Hudson, 2001; Jones, Myhill \& Bailey, 2013). Adult business-English ESL learners are commonly more interested in absorbing and understanding information that relates to their social roles and identities. It may therefore be useful for ESL instructors to ground subject matter in business contexts (Smith, 2002; Keller, 1983). There is not significant specificity to the grammatical rules governing English language as it relates to business usage and practice, and therefore, using subject matter that engages and motivates students may help them practice grammatical usage of English without using specifically rules-based grammatical instruction.

\section{Discussion And CONClusions}

Literature sources support the importance of both grammatical understanding - implicit or explicit and also listening comprehension in learning English for business or for other purposes. Listening is 
highlighted as the primary input mode for any language to be learned to fluency and coherence. Learning English can be inherently challenging due to idiomatic use, prevailing speech rate and diverse pronunciation styles and regional accents. These factors and elements relate to both the importance of listening in ESL learning for business and the function of grammatically-based instruction in developing confident and coherent communicators. Fluency and coherence in business English are some of the more challenging elements for business ESL learners, and yet both are critically important and intimately connected to a foundational grammatical understanding of the language. Understanding, fluency and coherence can be understood as being founded on grammatical rules and learning, whether this learning takes place in a prescriptive, rules-based context or one in which grammatical knowledge is exposed and absorbed in a more intuitive approach. If the latter approach is taken to ESL learning for business, a majority of practice will be undertaken through listening-based learning. Much of the literature underscores the concept that listening is the primary input channel for learning any language, and this of course includes English as it relates to a business ESL context. Intersecting aspects and factors may affect the development of English language learners in a business context.

Does a grammatically-based approach to business ESL education improve outcomes for students? It can be concluded that a grammatically-based approach to ESL education is necessary, at least to some degree, for all students of English or any other language. However, specifically grammar-based approaches have several possible negative outcomes. One is a general lack of student engagement with, or enthusiasm for, an ESL learning process that relies heavily on learning the rules of grammar instead of learning a wide range of vocabulary, subject matter and the social or cultural context of the language being studied. Motivation is an important factor in learning a language, and the literature seems to indicate that an explicitly grammar-based approach reduces the enjoyment and motivation experienced by students in learning English. Additionally, a grammar-focused approach to ESL instruction for business is likely to rely primarily upon written and reading materials, whereas many researchers indicate that language learning and comprehension occurs primarily through the input of listening. In the business-practice context, much of the English language usage encountered by students is likely to be verbal, and therefore a focus on listening at the student level is likely to be beneficial.

A listening-based approach - in addition to being accessible and practical for distance or online learners - can be used to generalize grammatical knowledge that students have already acquired through explicit or implicit grammatically-based instruction. Therefore, the conclusion and recommendations for future ESL education in the business field would be to design instruction that is highly grammar-based, without making this grammatical focus explicit to students. Rather, grammatical knowledge should be laid as a foundation before being implemented and practised through diverse listening materials and tasks. This will allow the business ESL student to learn English grammar through significant listening practice as being more practical.

\section{REFERENCES}

[1] Adank, P., Evans, B. G., Stuart-Smith, J., Scott, S. K. (2009). Comprehension of familiar and unfamiliar native accents under adverse listening conditions. Journal of Experimental Psychology: Human Perception and Performance, 35(2), 520-529.

[2] Akkoyunlu, B., \& Soylu, M. (2008). A study of student's perceptions in a blended learning environment based on different learning styles: http://www.ifets.info/journals/11_1/13.pdf

[3] Bandura, A. (1997). Self-efficacy: The exercise of control. New York, NY: W.H. Freeman.

[4] Bejar, I., Douglas, D., Jamieson, J., Nissan, S., \& Turner, J. (2000). TOESL 2000 listening framework: A working paper. (TOESL Monograph Series No. MA-19). Princeton, NJ: Educational Testing Service.

[5] Bell, A., Brenier, J., Gregory, M., Girand, C., \& Jurafsky, D. (2009). Predictability Effects on Durations of Content and Function Words in Conversational English. Journal of Memory and Language, 60(1), 92-111.

[6] Blau, E. K. (1990). The effect of syntax, speed and pauses on listening comprehension. TESOL Quarterly, 24(4), 746-753.

[7] Bloomfield, Amber, Sarah C. Wayland, Elizabeth Rhoades, Allison Blodgett, Jared Linck, and Steven Ross (2000). What makes listening difficult? Factors affecting second language listening comprehension. University of Maryland. College Park. 
[8] Boekaerts, M., \& Niemivirta, M. (2000). Self-regulated learning: Finding a balance between learning goals and ego-protective goals. In M. Boekaerts, P. R. Pintrich, \& M. Zeidner (Eds.), Handbook of self-regulation: Theory, research, and applications (pp. 417-450). San Diego, CA: Academic Press.

[9] Bordens, K. S., \& Abbott, B. B. (2008). Research Design and Methods (Eleventh ed.). 1221 Avenues of the Americas, New York, NY 10020: McGraw-Hill.

[10] Chang, Y.L., Chang, T.S., \& Kuo, C.H. (1995). Listening difficulties and learner strategies of nonnative speakers. The ninth Conference on English Teaching and Learning in the Republic of China (pp.145-158). Taipei: Crane.

[11] Chapelle, C. (2003). English language learning and technology: Lectures on applied linguistics in the age of information and communication technology(Vol. 7). John Benjamins Publishing.

[12] Chen, S. W. (2002). Problems in listening comprehension for learners of EFL. Studies in English Language and Literature, 10, 57-70.

[13] Chiang, Ch. S., \& Dunkel, P. (1992). The effect of speech modification, prior knowledge, and listening proficiency on EFL lecture learning. TESOL Quarterly, 26, 345-374.

[14] Chin, B. A. (2005). The role of grammar in improving student's writing. University of Montana.

[15] Cialdini, R. B. (1993). Influence: The psychology of persuasion. New York: Harper Business.

[16] DuBois, J.M. (2007). Ethics in Mental Health Research: Principles, Guidance and Cases Oxford: Oxford University Press.

[17] Faizah, A., \& Hazadiah, M. (2010). An assessment of 21st century adult learners' needs: issues and challenges for institutions of higher education. Available: http://education.uitm.edu.my/v1/ images/stories/publication/faizah/article1.pdf

[18] Freire, M. M. (2013). Complex educational design: a course design model based on complexity. Campus-Wide Information Systems, 30(3), 174-185.

[19] Gilakjani,A.P. and Ahmadi, M.R. (2011). A Study of Factors Affecting EFL Learners' English Listening Comprehension and the Strategies for Improvement. Journal of Language Teaching and Research, Vol. 2, No. 5, pp. 977-988.

[20] Greenland S., \& O' Rourke, K. (2008). 'Meta-Analysis.' in Modern Epidemiology, 3rd ed. Edited by Rothman KJ, Greenland S, Lash T. Lippincott Williams and Wilkins.

[21] Hamouda, A. (2013). An investigation of listening comprehension problems encountered by Saudi students in the EL listening classroom. International Journal of Academic Research in Progressive Education and Development,2(2), 113-155.

[22] Hasan, A. S. (2000). Learners' perceptions of listening comprehension problems. Language Culture and Curriculum, 13(2), 137-153.

[23] Hayati, A. (2010). The Effect of Speech Rate on Listening Comprehension of EFL learners. Creative Education, 2010, 2, 107-114.

[24] Hellalet, N. (2013). Textual coherence in EFL student writing. IOSR Journal Of Humanities And Social Science (IOSR-JHSS), 15(3), 54-58.

[25] Hinkel, E. (2013). Research Findings on Teaching Grammar for Academic Writing. English Teaching, 68(4), 3-20.

[26] Hudson, R. (2001). Grammar teaching and writing skills: the research evidence. Syntax in the Schools, 17(1), 1-6.

[27] Jones, S., Myhill, D., \& Bailey, T. (2013). Grammar for writing? An investigation of the effects of contextualised grammar teaching on students' writing. Reading and Writing, 26(8), 12411263.

[28] Keller. (1983). Development and use of the ARCS model of motivational design. Journal of Instructional Development. 10(3), 2-10.

[29] Lancaster, Z. \& Olinger, A.R. (2014). Teaching Grammar-in-Context in College Writing Instruction: An Update on the Research Literature. WPA-CompPile Research Bibliographies, No. 24, April 2014, 1-22.

[30] Lin, S. H. (2000). A study of English listening comprehension strategies used by senior high school students in Taiwan. Unpublished Master's thesis, National Kaohsiung Normal University, Kaohsiung City, Taiwan, R.O.C.

[31] Marshall, G. (2005). The purpose, design and administration of a questionnaire for data collection. Radiography, 11(2), 131-136.

[32] Micciche, L. R. (2004). Making a case for rhetorical grammar. College Composition and Communication, 55(4), 716-737. 
[33] Noguchi, R. R. (1991). Grammar and the Teaching of Writing: Limits and Possibilities. Urbana, IL: National Council of Teachers of English.

[34] O'Malley, J. M., Chamot, A. U., \& Kupper, L. (1989). Listening Comprehension Strategies in Second Language Acquisition. Applied Linguistics, 10(4), 418-437.

[35] Richards, J. C., \& Rodgers, T. S. (2014). Approaches and methods in language teaching. Cambridge University Press.

[36] Ridley, D. (2013). The Literature Review: A Step-by-Step Guide for Students. United States: SAGE Publishing.

[37] Rost, M. (2002). Teaching and Researching Listening. London: Longman.

[38] Rovai, A., \& Jordan, H. (2004). Blended Learning and Sense of Community: A comparative analysis with traditional and fully online graduate courses. International Review of Research in Open and Distance Learning, 1-12.

[39] Shen, Y. (2012). Reconsidering English Grammar Teaching for Improving Non-English Majors' English Writing Ability. English Language Teaching, 5(11), 74-78.

[40] Smith, M. K. (2002). 'Malcolm Knowles, informal adult education, self-direction and andragogy', the encyclopedia of informal education.

[41] Steinert, Y., \& Mann, K. V. (2006). Faculty development: principles and practices. Journal of Veterinary Medical Education, 33(3), 317-324.

[42] Williams, J. D. (2011). Teaching Grammar in the Context of Writing. Concepts in Composition: Theory and Practice in the Teaching of Writing, 267-316. New York: Routledge.

[43] Zhao, Y. (2013). Recent developments in technology and language learning: A literature review and meta-analysis. CALICO journal, 21(1), 7-27. 